Document downloaded from:

http://hdl.handle.net/10251/36965

This paper must be cited as:

Puertas Medina, RM.; Martí Selva, ML.; Garcia Menendez, L. (2013). LOGISTICS PERFORMANCE AND EXPORT COMPETITIVENESS: EUROPEAN EXPERIENCE. Empirica. 1-14. doi:10.1007/s10663-013-9241-z.

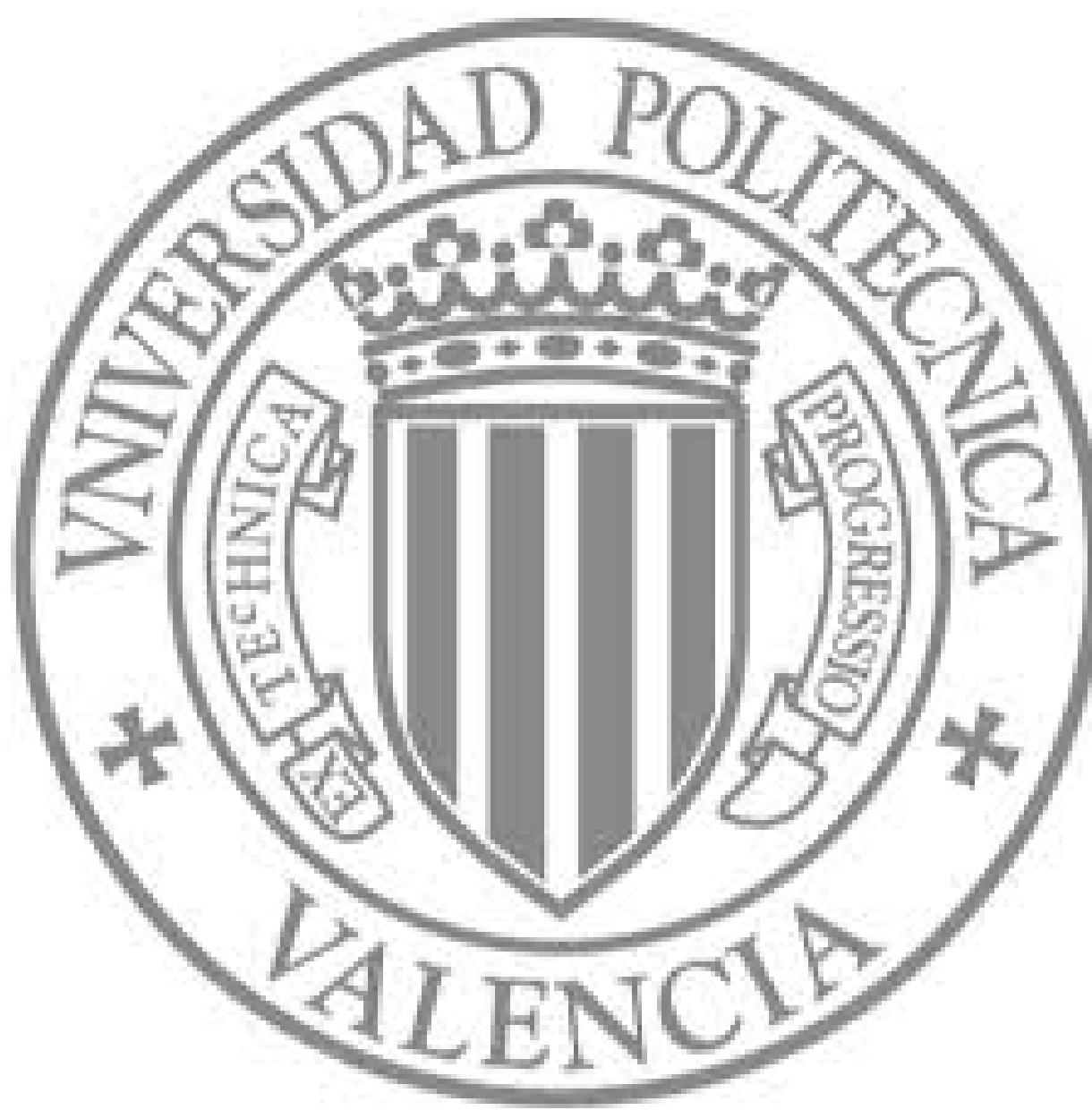

The final publication is available at

http://dx.doi.org/10.1007/s10663-013-9241-z

Copyright Springer Verlag (Germany) 


\title{
LOGISTICS PERFORMANCE AND EXPORT COMPETITIVENESS: EUROPEAN EXPERIENCE
}

\author{
ROSA PUERTAS \\ Grupo de Economía Internacional. Universidad Politécnica de Valencia. Spain. \\ Telf. 0034963.877000 ext. 79955/Fax. 963877479 \\ Email: rpuertas@esp.upv.es \\ LUISA MARTI \\ Grupo de Economía Internacional. Universidad Politécnica de Valencia. Spain. \\ Telf. 0034963.877000 ext. 74756/Fax. 963877479 \\ Email: mlmarti@esp.upv.es \\ LEANDRO GARCÍA \\ Instituto de Economía Internacional. Universidad de Valencia. Spain \\ Telf. 00349638283 45/ Fax. 963828334 \\ Email: Leandro.garcia@uv.es
}

\begin{abstract}
This article aims to analyse the importance of logistics performance in European Union (EU) exports over a sample period in order to detect possible advances on behalf of Member States. We will estimate several gravity equations using the Logistics Performance Index (LPI) and its components as characteristic proxy variables of trade facilitation. In order to avoid the possible heterogeneity caused by sample bias, we will employ the two-stage model proposed by Heckman. The estimations of the gravity models using the two-stage Heckman model for 26 EU countries lead to the conclusion that logistics were more important for exporting nations than importing nations in both 2005 and 2010, reinforcing the interest in the exporter side of the paper. In reference to the components of the LPI, Competence and Tracking have acquired greater importance in recent years, in keeping with the weak domestic demand in European countries and their search for new international markets.
\end{abstract}

Keywords: logistic performance index, trade, European Union, gravity

JEL: C5, F1, H54

\section{Introduction}


The research area of logistics originally focused on analysing the supply chain in order to achieve an optimum flow of the components necessary for production processes. However, market globalisation and modernisation have broadened the scope of this area to include spatial and temporal relationships. Purchasers and sellers contract logistics services to transport cargo from the point of origin to the point of destination. Authors such as Langley et al. (2008), Mangan et al. (2008), Rushton et al. (2009) and CILT (2012) have updated the definition of the term logistics. All of these authors agree that logistics is an integrated information, packaging, storage and transport system that fulfils demands in terms of time, quality, quantity and cost and that performance is crucial for competitiveness.

At present, international trade requires the organisation and synchronisation of flows through nodes and strategic networks that provide storage, conservation or any other type of value added service that the characteristics of the goods being transported require. There have been many improvements: terminals, regional and long-distance routes, infrastructures (enlargement and modernisation of ports and airports, together with wide access roads to logistics nodes) and logistics platforms and distribution centres have located bearing supply, demand and optimum areas for intermodality in mind. All of these improvements have markedly facilitated goods trade and have also led to a significant reduction in costs.

As stated by the World Bank (2010), both trade policy and logistics must take into account their impact on trade competitiveness. In recent years, this task has been aided by the publication of the Logistics Performance Index (LPI), which has provided valuable information on the situation in each country. This index makes it possible to establish comparisons and overcome the obstacles that restrict economic development. It is becoming increasingly necessary to identify the shortfalls that exist in logistics performance that affect export and import capacity, which is why trade facilitation measures are becoming so important (Jane, 2011).

The term "trade facilitation" has received considerable attention from researchers over the past few decades. The WTO defines it as the "simplification and harmonisation of international trade procedures”, the latter being understood as the necessary activities, practices and formalities to submit, gather and process the information required in international goods trade. Although many other definitions exist, they all agree that trade facilitation focuses on the quality of the trade environment and its impact on trade 
operations. All of the above highlights the close relationship between trade facilitation and logistics (Hollweng and Wong, 2009), terms which refer to the regulatory restrictions and performance of the logistics sector, respectively.

The literature includes research centred on logistics in the European Union (EU). In this sense it is worth mentioning Keskin (2012), who describes the logistics scenario in the EU concluding that without a common strategy, the EU will not be able to compete with trade rivals such as the US and China. Furthermore, Vilko et al. (2011) linked logistics to growth, focusing on countries in Eastern Europe, and found that a country with insufficient infrastructure can grow if that infrastructure is used in an innovative way, as in the case of Estonia.

The number of Member States, the chronology of the community enlargement process and the heterogeneous level of logistics performance means the European Union has great interest in assessing the impact of logistics actions on trade. All governments and multilateral organisations implement plans, programs and projects with the intention of boosting logistics performance. However, it must be said that the community experience is extremely interesting, as countries with backward logistics infrastructure are quickly incorporating the procedures used by the countries at the vanguard of logistics performance.

This article aims to analyse the importance of logistics performance for EU exports over the period 2005-2010 in order to detect possible advances on behalf of Member States. We will estimate several gravity equations using the LPI and its components as variables to proxy the characteristics of trade facilitation.

The article is organised into the following sections. Section 2 specifies the theoretic framework of the research. Section 3 details the methodology applied to the gravity models and the sample used in the empirical part of the research. Section 4 presents the results of the gravity model estimation and finally, Section 5 summarises the main conclusions.

\section{Theoretical Framework}

The theoretical framework to study the influence of logistics on trade flows is based on gravity equations. Gravity models began to obtain sound theoretical groundings from 
the 1970s onwards after being applied to various contexts in economics (Anderson, 1979; Bergstrand, 1985, 1989; Helpman and Krugman, 1985; Breuss and Egger, 1999; Anderson and van Wincoop, 2003; Requena and Llano, 2010). An analogy of Newton’s gravitational attraction, the basic model considers that bilateral trade flows depend positively on the income of the two economies and negatively on the distance that separates them, apart from including other dummy variables that capture the qualitative effects that influence the exports of a country (language, border, etc.).

Returning to the objective of the article, we will estimate a gravity model to identify the determinants of European exports, assigning special importance to the weighting of logistics and how this variable has developed since 2005. In order to avoid the possible heterogeneity caused by sample bias, we will use the two-stage model proposed by Heckman. More specifically, the gravity equation will be as follows:

$$
\begin{aligned}
& \log \left(\mathrm{X}_{i j}\right)=\beta_{0}+\beta_{1} \log \left(\mathrm{D}_{\mathrm{i}}\right)+\beta_{2} \log \left(\mathrm{Y}_{\mathrm{i}}\right)+\beta_{3} \log \left(\mathrm{Y}_{\mathrm{j}}\right)+\beta_{4} \log \left(\mathrm{P}_{\mathrm{i}}\right)+ \\
& +\beta_{5} \log \left(\mathrm{P}_{\mathrm{j}}\right)+\beta_{6} \log \left(\mathrm{LPI}_{\mathrm{i}}\right)+\beta_{7} \log \left(\mathrm{LPI}_{\mathrm{j}}\right)+\beta_{\mathrm{A}} \mathrm{W}+\mathrm{u}_{\mathrm{ij}}
\end{aligned}
$$

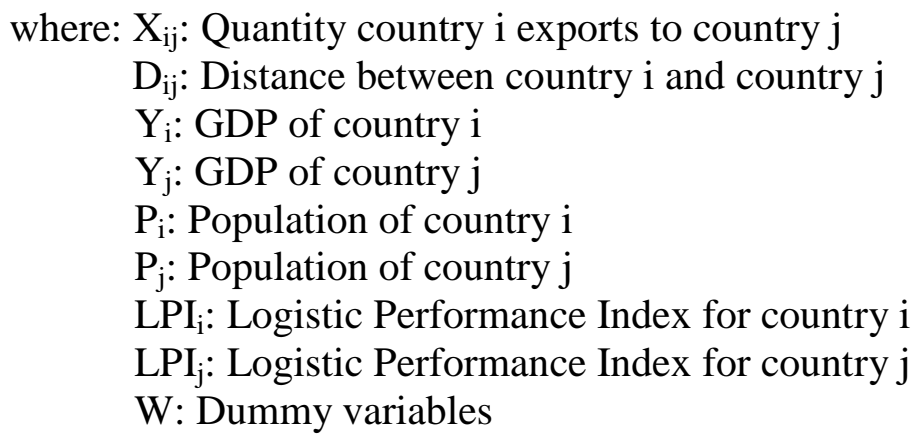

According to equation (1), exports depend on economic, geographic and demographic variables together with logistics variables. The effect of distance between countries $\left(\beta_{1}\right)$ should be negative and statistically significant, because proximity promotes trade. Theoretically, the GDP coefficients of both the exporter and also the importer ( $\beta_{2}$ and $\beta_{3}$ ) will be positive and statistically significant. The reason for this is that the larger an economy is, regardless of whether the country is buying or selling, the more exports and imports can be expected. Furthermore, the population coefficient for the exporting country $\left(\beta_{4}\right)$ could be positive or negative depending on whether the most populated country exports less due to absorbing domestic production, or exports more due to technological and logistics variables associated to the level of economic development 
predominating. At the same time, the sign of the importer population coefficient $\left(\beta_{5}\right)$ is also ambiguous for the same reasons as those stated above.

In accordance with the objective of this research, we include the exporter and importer LPI in the gravity model. Both variables have coefficients $\left(\beta_{6}\right.$ and $\left.\beta_{7}\right)$ that represent the importance of trade facilitation in export flows. Consequently, a positive sign is expected in both cases. Finally, a series of dummy variables represent the existing social and cultural similarities between countries in the geographical regions analysed (Border, official languages, second languages, colonisers).

The study also focuses on analysing the importance of each LPI component in trade flows. The fact that the components of the LPI are markedly correlated means it is not feasible to estimate one single equation including all the components, as doing so would lead to multicollinearity and erroneous results. Therefore, regressions similar to equation (1) have been estimated, including each index component separately. As a result, the following equations have been formulated:

$\log \left(\mathrm{X}_{\mathrm{ij}}\right)=\beta_{0}+\beta_{1} \log \left(\mathrm{D}_{\mathrm{i}}\right)+\beta_{2} \log \left(\mathrm{Y}_{\mathrm{i}}\right)+\beta_{3} \log \left(\mathrm{Y}_{\mathrm{j}}\right)+\beta_{4} \log \left(\mathrm{P}_{\mathrm{i}}\right)+$

$+\beta_{5} \log \left(\mathrm{P}_{\mathrm{j}}\right)+\beta_{6} \log \left(\right.$ Customs $\left._{\mathrm{i}}\right)+\beta_{7} \log \left(\right.$ Customs $\left._{\mathrm{j}}\right)+\beta_{\mathrm{A}} \mathrm{W}+\mathrm{u}_{\mathrm{ij}}$

$\log \left(X_{i j}\right)=\beta_{0}+\beta_{1} \log \left(D_{i}\right)+\beta_{2} \log \left(Y_{i}\right)+\beta_{3} \log \left(Y_{j}\right)+\beta_{4} \log \left(P_{i}\right)+$

$+\beta_{5} \log \left(\mathrm{P}_{\mathrm{j}}\right)+\beta_{6} \log \left(\right.$ Infrastructure $\left._{\mathrm{i}}\right)+\beta_{7} \log \left(\right.$ Infrastructure $\left._{\mathrm{j}}\right)+\beta_{\mathrm{A}} \mathrm{W}+\mathrm{u}_{\mathrm{ij}}$

$\log \left(X_{i j}\right)=\beta_{0}+\beta_{1} \log \left(D_{i}\right)+\beta_{2} \log \left(Y_{i}\right)+\beta_{3} \log \left(Y_{j}\right)+\beta_{4} \log \left(P_{i}\right)+$

$+\beta_{5} \log \left(\mathrm{P}_{\mathrm{j}}\right)+\beta_{6} \log$ (International shipments $\left.\mathrm{s}_{\mathrm{i}}\right)+\beta_{7} \log$ (International shipments $\left.\mathrm{s}_{\mathrm{j}}\right)+\beta_{\mathrm{A}} \mathrm{W}+\mathrm{u}_{\mathrm{ij}}$

$\log \left(X_{i j}\right)=\beta_{0}+\beta_{1} \log \left(D_{i}\right)+\beta_{2} \log \left(Y_{i}\right)+\beta_{3} \log \left(Y_{j}\right)+\beta_{4} \log \left(P_{i}\right)+$

$+\beta_{5} \log \left(\mathrm{P}_{\mathrm{j}}\right)+\beta_{6} \log \left(\right.$ Competence $\left._{\mathrm{i}}\right)+\beta_{7} \log \left(\right.$ Competence $\left._{\mathrm{j}}\right)+\beta_{\mathrm{A}} \mathrm{W}+\mathrm{u}_{\mathrm{ij}}$

$\log \left(X_{i j}\right)=\beta_{0}+\beta_{1} \log \left(D_{i}\right)+\beta_{2} \log \left(Y_{i}\right)+\beta_{3} \log \left(Y_{j}\right)+\beta_{4} \log \left(P_{i}\right)+$

$+\beta_{5} \log \left(\mathrm{P}_{\mathrm{j}}\right)+\beta_{6} \log \left(\right.$ Tracking $\left._{\mathrm{i}}\right)+\beta_{7} \log \left(\right.$ Tracking $\left._{\mathrm{j}}\right)+\beta_{\mathrm{A}} \mathrm{W}+\mathrm{u}_{\mathrm{ij}}$

$\log \left(X_{i j}\right)=\beta_{0}+\beta_{1} \log \left(D_{i}\right)+\beta_{2} \log \left(Y_{i}\right)+\beta_{3} \log \left(Y_{j}\right)+\beta_{4} \log \left(P_{i}\right)+$

$+\beta_{5} \log \left(\mathrm{P}_{\mathrm{j}}\right)+\beta_{6} \log \left(\right.$ Timeliness $\left._{\mathrm{i}}\right)+\beta_{7} \log \left(\right.$ Timeliness $\left._{\mathrm{j}}\right)+\beta_{\mathrm{A}} \mathrm{W}+\mathrm{u}_{\mathrm{ij}}$

Each component is initially expected to display a significant and positive sign, such that higher values of these variables favour international trade. By comparing the results of the estimation, we will be able to ascertain which component has the greatest impact on trade flows and also the changes it has undergone over the period dating from 2005 to 2010. 
A key issue estimating gravity models is how to deal with zero bilateral trade. Theoretically, zero trade might not be missing information and zero-trade may actually be reflecting the absence of any trade between country pairs. Frequently, the zeros are not randomly distributed, which leads to the problem of selection bias if zero trade observations were to be dropped. Recent Literature illustrates that a sample selection bias can arise if the gravity model is estimated by OLS. To deal with this problem Heckman (1979) propose the use of Heckman two-step procedure. This procedure entails first estimating a probit model that determines the probability that a country pair engages in trade. Next, a gravity regression with a selectivity variable obtained from the probit regression. In our estimates we use the Heckman model to avoid sample selection bias.

\section{Data}

The theoretical framework examined in the previous section is the perfect foundation to study the effect of logistics performance on trade flows, even though the lack of availability of variables (or proxy variables) that can be included has delayed this analysis. For this reason, the LPI published by the World Bank ${ }^{1}$ is a valuable new source that extends the gravity model by incorporating a determinant of EU Member State exports. As mentioned previously, this index is one of the referents for comparing countries' logistics. The World Bank has published the index for 150 countries and for three years (Arvis et al. 2005, 2008 y 2010) distinguishing six components:

- Customs: measures the efficiency and effectiveness of the customs despatch procedure (speed, simplicity and predictability of customs agencies).

- Infrastructure: measures the quality of the country's transport and telecommunications infrastructure.

- International shipments: measures how easy it is to arrange shipments at competitive prices.

- $\quad$ Logistics quality and competence: measures the competence and quality of logistics services.

\footnotetext{
${ }^{1}$ The LPI has been used in other articles to ascertain the quality of trade facilitation (Hertel and Mirza, 2009; Felipe and Kumar, 2010).
} 
- $\quad$ Tracking and tracing: measures the tracking and tracing of shipments.

- $\quad$ Timeliness: measures shipment delivery time punctuality.

The values of the LPI and its components range from 1 to 5, 1 being the worst score.

The evolution of logistics across EU member States was disparate between 2005 and 2010 (see Grafic A1 and A2 in the appendix). More specifically, nine nations have witnessed a decrease in their LPI, while the rest have registered increases ranging from $0.32 \%$ in the case of the Czech Republic to $12.83 \%$ for Poland. As regards the countries that have registered decreases, it is worth highlighting the cases of Greece, Ireland and Latvia, down by $15.77 \%, 9.97 \%$ and $7.95 \%$ respectively. However, it is important to indicate that European countries are well placed in the ranking of 150 countries. In reference to 2010, six EU member States are among the top 10 countries, which confirms that logistics is a priority for Europe.

The sample the study uses is made up of 26 exporting countries that belong to the EU (the only member State removed from the sample is Malta, due to a lack of LPI data) and 124 importing countries $^{2}$ for which the World Bank publishes the LPI. The information on trade flows comes from the Comtrade database (United Nations). As regards the explanatory variables, distance between countries expressed in kilometres has been calculated as the straight-line distance between capitals, which acts as an initial estimation in view of the difficulty involved in locating producer regions that are often spread across the territory of exporting and importing countries. GDP (in dollars) and population data have been obtained from the United Nations database and the LPI for exporters and importers come from the World Bank. Finally, the series of dummy variables that describe the social and cultural features of countries that make up the areas have been obtained from CEPII.

\section{Results}

The results obtained from estimating the gravity model reveal for 2005 that the most important variable is importer GDP, which coincides clearly with the gravity equation

\footnotetext{
${ }^{2}$ The 26 European countries have been removed to only consider extra-community exports.
} 
literature $^{3}$. That variable is followed by Distance and in third place Logistics Performance (LPI). In fact, the same ranking is obtained from the estimation considering both the aggregate index (1st column, Table 1A) and also each of the estimations performed with the different components of the index.

The estimation for 2010 confirms these conclusions; although there are some noteworthy clarifications (see Table 2A in the appendix). The overall significance of the results remains unchanged, importer GDP is still the most important variable, the exporter LPI score drops in regard to 2005 and, in contrast, importer LPI improves slightly, albeit remaining below the former, confirming the emphasis from the exporter perspective.

Nevertheless, the main result of the comparison between 2005 and 2010 is the confirmation of the important role that the LPI plays as an explanatory variable of exports, behind importer GDP, but with a similar weighting to the variables traditionally included in gravity models.

In order to provide the overall picture of the situation, Tables 1 and 2 include all the results for 2005 and 2010 regarding logistics performance according to the aggregate LPI and for each of its components. The results for 2005 display a high level of significance, both for the LPI and all its components (Table 1).

Table 1. Logistics coefficients EU-26. Period 2005.

\begin{tabular}{|lr|}
\hline Second-stage Heckman procedure & Coefficients \\
\hline Log LPI export & $.353^{* *}$ \\
Log LPI import & $.133^{* * *}$ \\
\hline Log Customs export & $.357^{* * *}$ \\
Log Customs import & $.084^{* * *}$ \\
\hline Log Infraestructure export & $.333^{* * *}$ \\
Log Infraestructure import & $.131^{* * *}$ \\
\hline Log International shipments export & $.147^{* * *}$ \\
Log International shipments import & $.162^{* * *}$ \\
\hline Log Competence export & $.475^{* * *}$ \\
Log Competence import & $.125^{* * *}$ \\
\hline Log Tracking export & $.358^{* * *}$ \\
Log Tracking import & $.128^{* * *}$ \\
\hline
\end{tabular}

\footnotetext{
${ }^{3}$ The coefficients of all the variables have been standardised to facilitate comparison
} 


\begin{tabular}{|ll|}
\hline Log Timeliness export & $.221^{* * *}$ \\
Log Timeliness import & $.045^{* * *}$ \\
\hline Note: ${ }^{*}$ p-value $<0.1,{ }^{* *}$ p-value $<0.05,{ }^{* * *}$ p-value $<0.01$ & \\
\hline
\end{tabular}

More specifically, two aspects stand out. In the first place, exporters record higher scores than importers, with the exception of International Shipments, which is coherent with the specification and reinforces the recommendation of designing exporter-based policies and interventions. The second prominent result refers to the value of the coefficients registered by the various sections of the index, Competence recording the highest score, followed by Tracking, Customs and Infrastructure, thereby evidencing the relevance of government policies and the level that the private sector has achieved.

Table 2 reveals once again that the figures are higher in the case of exporters, Competence, Infrastructure, Customs and Tracking figuring prominently, as was the case in 2005.

Table 2. Logistics coefficients EU-26. Period 2010.

\begin{tabular}{|c|c|}
\hline Second-stage Heckman procedure & Coefficients \\
\hline Log LPI export & $.251^{* * *}$ \\
\hline Log LPI import & $148^{* *}$ \\
\hline Log Customs export & $.229^{* * *}$ \\
\hline Log Customs import & $.084^{*}$ \\
\hline Log Infraestructure export & $.282^{* * *}$ \\
\hline Log Infraestructure import & $.141^{* *}$ \\
\hline Log International shipments export & $.135^{* * *}$ \\
\hline Log International shipments import & $.131^{* * *}$ \\
\hline Log Competence export & $.298^{* * *}$ \\
\hline Log Competence import & $.101^{*}$ \\
\hline Log Tracking export & $.213^{* * *}$ \\
\hline Log Tracking import & $.154^{* *}$ \\
\hline Log Timeliness export & $.091^{*}$ \\
\hline Log Timeliness import & $.126^{* * *}$ \\
\hline
\end{tabular}

The results obtained indicate that the more serious the crisis became from 2007 onwards, the more relevant the private sector components of the LPI became. Indeed, Competence explains a greater share of export flows, coinciding with the weak 
domestic demand in many European economies at the time and the search for export markets.

In view of the variety of macroeconomic and trade balance scenarios in European countries, we decided to divide EU countries into two groups on the basis of being above or below the average LPI. The first group comprises the Netherlands, Germany, Sweden, Austria, the United Kingdom, Ireland, Belgium, Denmark, Finland, France, Italy, Luxembourg and Spain, while the second group includes Portugal, Greece, Hungary, Slovenia, Czech Republic, Poland, Latvia, Estonia, Slovakia, Cyprus, Rumania, Bulgaria and Lithuania.

It is important to take into account that there are a variety of criteria for establishing the groups, particularly in regard to Portugal and Greece, who became members of the EU a long time before the rest of the countries in the second group. However, the low level of logistics performance in these two countries has resulted in their inclusion in this group. Similarly, the countries in the second group have a wide variety of levels of development, logistics performance and EU membership. For this reason, and despite attempting several different classifications, we finally opted for that described previously as we believe it is ideal for the purposes of this research. In this sense, we have estimated a gravity model for each of the two groups in order to detect possible patterns of behaviour.

The first group, which includes the countries where the logistics sector is most developed, records widespread significance for both the aggregate index and also all its components (Table 3). The maturity of the private logistics industry in these economies led in 2005 to very high coefficients in Timeliness, Tracking and Competence and, albeit to a lesser extent, in Infrastructures and Customs. In 2010, Infrastructure registered the highest score, followed by Customs and Tracking. In fact, these results are evidence of a global public and private response to logistics performance that has led to a stable and consolidated logistics scenario regardless of the specific values recorded by parameters in any given year.

Table 3. Logistic performance of first group countries

\begin{tabular}{|l|c|c|}
\hline Second-stage Heckman procedure & 2005 & 2010 \\
Coefficients & Coefficients \\
\hline
\end{tabular}




\begin{tabular}{|l|l|l|}
\hline Log LPI export & $.120^{* * *}$ & $.127^{*}$ \\
\hline Log Customs export & $.102^{* * *}$ & $.125^{* *}$ \\
\hline Log Infraestructure export & $.172^{* * *}$ & $.148^{*}$ \\
\hline Log International shipments export & $.056^{* *}$ & $.056^{* * *}$ \\
\hline Log Competence export & $.364^{* * *}$ & $.115^{* *}$ \\
\hline Log Tracking export & $.453^{* * *}$ & $.125^{*}$ \\
\hline Log Timeliness export & $.533^{* * *}$ & $.102^{* *}$ \\
\hline
\end{tabular}

Note: ${ }^{*} \mathrm{p}$-value $<0.1,{ }^{* *}$ p-value $<0.05,{ }^{* * *}$-value $<0.01$

In contrast, the second group displays disappointing results in 2005, as neither the aggregate index nor its components Competence, Tracking or Timeliness are significant (Table 4). Consequently, private sector activity in the logistics sector in these countries is weak and more akin to patterns that are more typical of emerging nations than the EU Member States before the most recent enlargement processes. However, the two components most closely linked to government policy, namely Customs and Infrastructure, are significant and register acceptable coefficients. In sum, in 2005 there was a clear divide in this group between the components that are influenced by government policy and those pertaining to the private sector as regards achieving efficient logistics performance in the interest of export competitiveness.

However, the data for the same group in 2010 reveal hugely interesting changes, despite there being a difference of only five years between the two sample years (see Table 4).

Table 4. Logistic performance of second group countries

\begin{tabular}{|l|c|c|}
\hline Second-stage Heckman procedure & $\begin{array}{c}\mathbf{2 0 0 5} \\
\text { Coefficients }\end{array}$ & $\begin{array}{c}\mathbf{2 0 1 0} \\
\text { Coefficients }\end{array}$ \\
\hline Log LPI export & .013 & $.060^{* *}$ \\
\hline Log Customs export & $.148^{*}$ & $.061^{* * *}$ \\
\hline Log Infraestructure export & $.059^{* *}$ & $.080^{* * *}$ \\
\hline Log International shipments export & $-.062^{*}$ & $.035^{* *}$ \\
\hline Log Competence export & .166 & $.304^{* * *}$ \\
\hline Log Tracking export & -.018 & $.040^{* *}$ \\
\hline Log Timeliness export & -.083 & -.0025 \\
\hline
\end{tabular}

This group records widespread significance in 2010, quite unlike the scenario in 2005. The aggregate index is significant, as is the case with Customs, Infrastructure, 
Contracting, Competence and Tracking, Timeliness being the only non significant component. As was the case in 2005, the components linked to government policy remain significant, but unlike that year, the components that capture the logistics performance of the private sector are significant, particularly Competence, which records the highest score.

These results are particularly interesting from the perspective of the European integration process. Although the values of the coefficients are lower than those achieved by the first group, it can be concluded that belonging to the EU has prompted a logistics performance that is benefiting exports and, more importantly, the private sector has contributed with strategies that boost competence and in turn performance.

The European economic crisis itself and the need to export have had a favourable influence on the changes detected, but also that the adoption of European policy is resulting in these European countries being remarkably successful in this respect. Issues such as the modernisation of customs services and the widespread acceptance of the figure of the authorised economic operator, the single foreign trade windows at ports, the incorporation of global private operators into port terminal management, the development of port community systems and, in turn, the ICTs at the services of the logistics chain, among other initiatives, have prompted greater competence, the coming of age of the 3PL supply, more regular shipping lines and have permitted to overcome the traditional model of the freight forwarder in favour of a mature model. In addition, the inclusion of these countries in the Trans-European Transport Networks has contributed to the provision of infrastructure that logically culminates in enhanced logistics performance.

\section{Conclusions}

The importance of logistics for international trade is a relevant aspect to take into account within the EU, due to the region being predominantly an exporter and made up of countries that have made an effort to develop their transport policy. This paper focuses on analysing the advances in logistics that EU member States have made in a five-year period using the LPI published by the World Bank as a proxy, together with its six components, namely Customs, Infrastructure, Competence, Contracting, Tracking and Timeliness. 
The estimations of the gravity equations using the two-stage Heckman model for the 26 EU countries have led us to conclude that the most influential for European exports is importer GDP, a result that is in keeping with economic theory. Distance is the second most influential, followed by Logistics Performance and this is the case in both 2005 and 2010. However, it is worth highlighting that logistics was more important for exporting nations than importing nations in both 2005 and 2010, coinciding with the results obtained by other studies for different geographical regions (Martí et al, 2012) and reinforcing the interest in the exporter focus of the paper. In reference to the components of the LPI, Competence and Tracking acquired greater importance in recent years, in keeping with the weak domestic demand in European countries and the search for new international markets.

After dividing the sample into the countries that recorded LPI values above the average and those that displayed values below that average, we can conclude that the coming of age of the private sector in 2005 resulted in the case of the first group of countries in Timeliness, Tracking and Competence representing an important share of the index, unlike the case of the second group, which registered low LPI values whereby most components turned out not to be significant. While the pass of time has not led to marked changes in the countries where logistics performance was already highly rated, the initially inefficient countries in 2005 went from recording generally non significant values, to the opposite. All of the above highlights the positive impact that European integration has had on certain countries. Being a member of the EU has benefited the enhancement of logistics performance in these weaker countries, which have at the same time increased their volume of exports.

In summary, we can conclude that the least developed countries in terms of logistics are making a significant effort to improve their situation, which is boosting international trade and their own economic growth. When the new LPI data are published by the World Bank in the near future, it would be interesting to verify whether the evident progress displayed over the period 2005-2010 continues and is coherent with the economic climate of the countries sampled. 


\section{References}

Anderson JE (1979) A theorical foundation to the gravity equation. Am Econ Rev 69: 106-116. Stable URL: http://www.jstor.org/stable/1802501

Anderson J, Van Wincoop E (2003) Gravity with gravitas: A solution to the border puzzle. Am Eco Rev 93: 170-192. doi: 10.1257/000282803321455214

Arvis JF, Mustra M, Ojala L, Shepherd B, Saslavsky D. (2005) Connecting to compete: Trade logistics in the global economy. World Bank, Washington

Arvis JF, Mustra M, Panzer J, Ojala L, Naula T (2007) Connecting to compete: Trade logistics in the global economy. World Bank, Washington

Arvis JF, Mustra M, Ojala L, Shepherd B, Saslavsky D (2010) Connecting to compete: Trade logistics in the global economy. World Bank, Washington

Bergstrand JH (1985) The gravity equation in international trade: Some microeconomic foundations and empirical evidence. Rev Econ Stat 71: 143-153. Stable URL: http/www.jstor.org/stable/1925975

Bergstrand JH (1989) The generalized gravity equation, monopolistic competition, and the factor-proportions theory in international trade. Rev Econ Stat 67: 474-481. Stable URL: http://www.jstor.org/stable/1928061

Breuss F, Egger P (1999) How reliable are estimations of east-west trade potencials based on cross-section gravity analysis? Empirica 26: 86-89. doi: 10.1023/A:1007011329676

CILT (2012) Available at http://www.ciltuk.org.uk/pages/royalcharter. Accessed $\underline{02.08 .12}$

Felipe J, Kumar U (2012) The role of trade facilitation in Central Asia: A gravity model. Eastern European Economics 50: 5-20. doi: 10.2753/EEE0012-875500401

Heckman J (1979) Sample selection bias as a specification error. Econometrica 47: 153161. Stable URL: http://www.jstor.org/stable/1912352

Helpman E, Krugman P (1985) Market structure and foreign trade. Increasing returns, imperfect competition and the international economy. The MIT Press, Cambridge, MA/London

Hertel T, Mirza T (2009) The role of trade facilitation in South Asian economic integration. Study on intraregional trade and investment in South Asia. ADB. Mandaluyong City

Hollweg C, Wong M-H (2009) Measuring regulatory restrictions in logistics services. ERIA Discussion Paper Series, no. 14

Jane C-C (2011) Performance evaluation of logistic systems under cost and reliability considerations. Transport Res E-Log 47: 130-137. doi:10.1016/j.tre.2010.09.012

Keskin MH (2012) The exigencies of the common logistics policy for European Community and the deconstruction of the common transportation policy. Afr $\mathrm{J}$ Bus Manage 6: 10697-10707. doi: 10.5897/AJBM11.1523

Langley C, Coyle J, Gibson B, Novak R, Bardi E (2008) Managing supply chain: A logistics approach. South-Western Cengage learning 
Mangan J, Lalwani C, Butcher C (2008) Global logistics and supply chain management. Weley Higher Education

Martí ML, Puertas R, García L (2012) Relevance of trade facilitation in emerging countries's export. J Int Trade Eco Dev. http://www.tandfonline.com/doi/abs/10.1080/09638199.2012.698639

Requena F, Llano C (2010) The border effects in Spain: An industrial-level analysis. Empirica 37: 455-476. doi: 10.1007/s10663-010-9123-6

Rushton A, Oxley J, Croucher P (2009) The handbook of logistics and distribution Management. Kogan Page

Vilko J, Karandassov B, Myller E (2011) Logistic infrastructure and its effects on economic development. China-USA Bus Rev 10: 1152-1167

World Bank (2010) Trade and transport facilitation assessment. A practical toolkit for country implementation. World Bank, Washington 
Annex

Grafic 1A. LPI European countries with better logistics

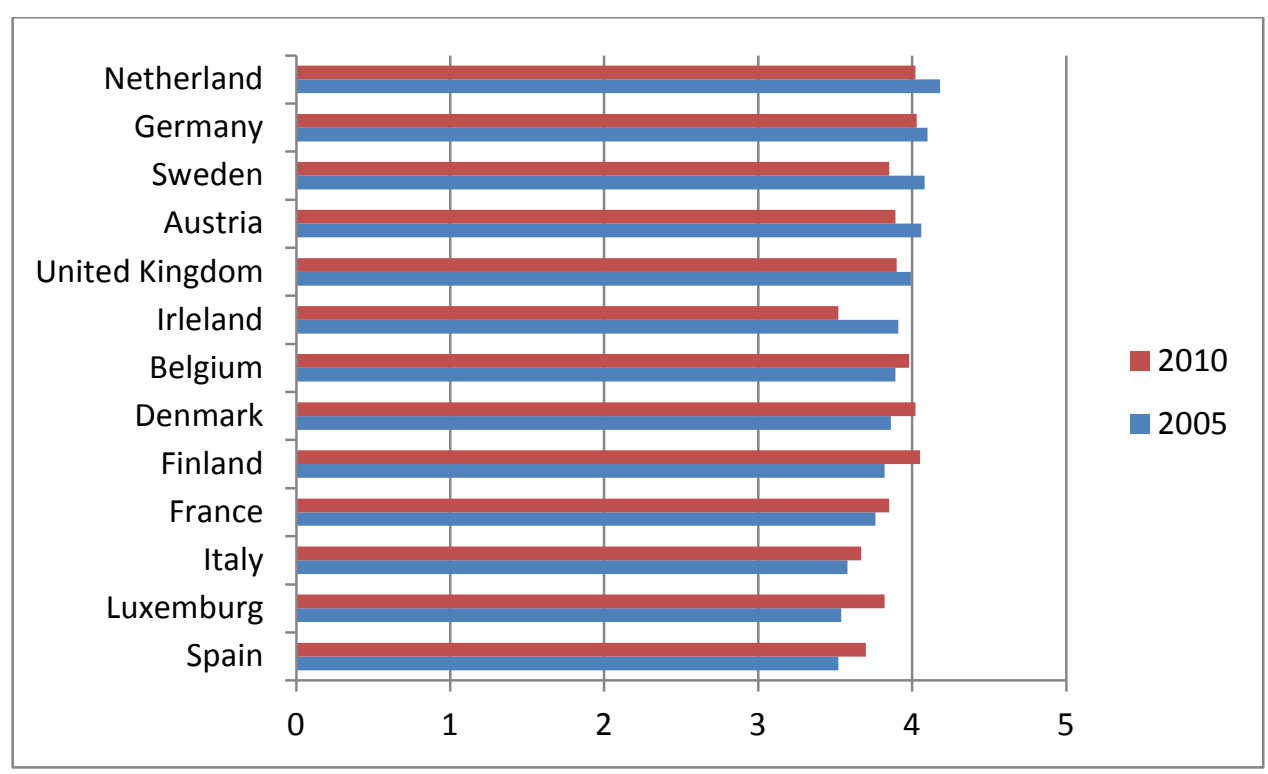

Source: Compiled from World Bank data Arvis et al. (2007and 2012)

\section{Grafic 2A. LPI European countries with poor logistics}

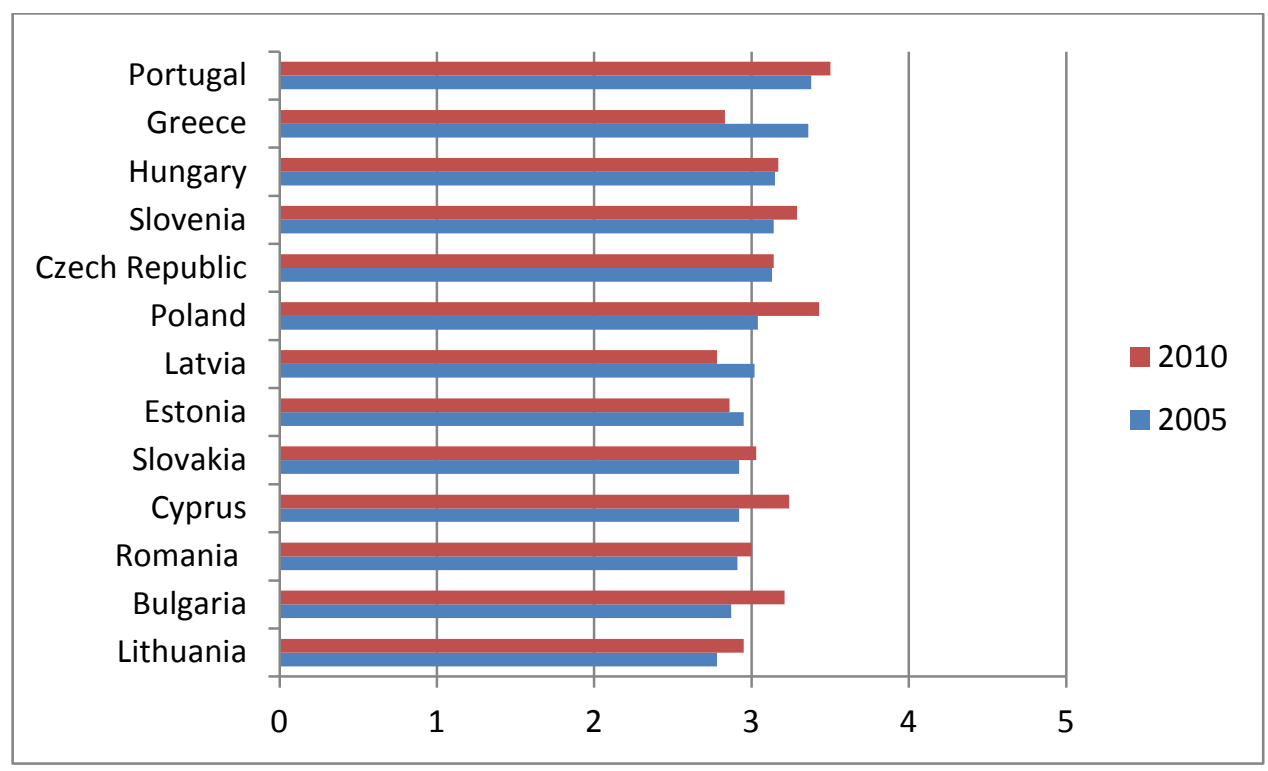

Source: Compiled from World Bank data Arvis et al. (2007and 2012) 
Table A1. Second-stage Heckman procedure. EU-26 Period 2005.

\begin{tabular}{|c|c|c|c|c|c|c|c|}
\hline & Eq (1) & $\mathrm{Eq}(2)$ & $\mathrm{Eq}(3)$ & $\mathrm{Eq}(4)$ & Eq (5) & $\mathrm{Eq}(6)$ & Eq (7) \\
\hline Log Distance & $-0.407^{* * *}$ & $-0.409^{* * *}$ & $-0.389^{* * *}$ & $-0.389^{* * *}$ & $-0.405^{* * *}$ & $-0.407^{* * *}$ & $-0.391^{* * *}$ \\
\hline Log GDP Exp & $0.307^{* * *}$ & $0.351^{* * *}$ & $0.160^{*}$ & $0.693^{* * *}$ & $0.388^{* * *}$ & $0.512^{* * *}$ & $0.751^{* * *}$ \\
\hline Log GDP Imp & $0.805^{* * *}$ & $0.825^{* * *}$ & $0.746^{* * *}$ & $0.832^{* * *}$ & $0.872^{* * *}$ & $0.848^{* * *}$ & $0.939^{* * *}$ \\
\hline Log Population Exp & $0.298^{* * *}$ & $0.315^{* * *}$ & $0.439^{* * *}$ & $0.022^{* * *}$ & 0.211 & $0.149^{* * *}$ & 0.019 \\
\hline Log Population Imp & 0.014 & 0.011 & $0.053^{* *}$ & $-0.002^{* * *}$ & -0.021 & -0.003 & $-0.053^{* *}$ \\
\hline Log LPI Exp & $0.353^{* * *}$ & & & & & & \\
\hline Log LPI Imp & $0.133^{* * *}$ & & & & & & \\
\hline Log Customs Exp & & $0.357^{* * *}$ & & & & & \\
\hline Log Customs Imp & & $0.084^{* * *}$ & & & & & \\
\hline Log Infraestructure Exp & & & $0.333^{* * *}$ & & & & \\
\hline Log Infraestructure Imp & & & $0.131^{* * *}$ & & & & \\
\hline Log Int Shipments Exp & & & & $0.147^{* * *}$ & & & \\
\hline Log Int Shipments Imp & & & & $0.162^{* * *}$ & & & \\
\hline Log Competence Exp & & & & & $0.475^{* * *}$ & & \\
\hline Log Competence Imp & & & & & $0.125^{* * *}$ & & \\
\hline Log Tracking Exp & & & & & & $0.358^{* * *}$ & \\
\hline Log Tracking Imp & & & & & & $0.128^{* * *}$ & \\
\hline Log Timeliness Exp & & & & & & & $0.221^{* * *}$ \\
\hline Log Timeliness Imp & & & & & & & $0.045^{*}$ \\
\hline Border & $0.029^{*}$ & $0.029^{*}$ & $0.033^{*}$ & $0.036^{* *}$ & $0.028^{*}$ & $0.030^{*}$ & $0.032^{*}$ \\
\hline Language & $0.064^{* * *}$ & $0.061^{* * *}$ & $0.276^{* * *}$ & $0.061^{* * *}$ & $0.069^{* * *}$ & $0.062^{* * *}$ & $0.065^{* *}$ \\
\hline Colony & $0.046^{* *}$ & $0.274^{* *}$ & $0.203^{* *}$ & $0.035^{* *}$ & $0.261^{* *}$ & $0.045^{* *}$ & $0.042^{* *}$ \\
\hline Mills Lambda & -0.029 & 0.036 & -0.317 & -0.265 & 0.047 & 0.076 & 0.111 \\
\hline
\end{tabular}

Note: ${ }^{*}$ p-value $<0.1,{ }^{* *}$ p-value $<0.05,{ }^{* * *}$ p-value $<0.01$ 
Table 2A. Second-stage Heckman procedure. EU-26 Period 2010

\begin{tabular}{|c|c|c|c|c|c|c|c|}
\hline & Eq (1) & Eq (2) & Eq (3) & Eq (4) & Eq (5) & Eq (6) & Eq (7) \\
\hline Log Distance & $-0.400^{* *}$ & $-0.423^{* * *}$ & $-0.401^{* * *}$ & $-0.427^{* * *}$ & $-0.413^{* * *}$ & $-0.405^{* * *}(0.002)$ & $-0.419^{* * *}$ \\
\hline Log GDP Exp & $0.334^{* *}$ & $0.389^{* * *}$ & $0.257^{*}$ & $0.563^{* * *}$ & $0.236^{*}$ & $0.396^{* * *}(0.002)$ & $0.633^{* * *}$ \\
\hline Log GDP Imp & $0.827^{* * *}$ & $0.892^{* * *}$ & $0.834^{* * *}$ & $0.857^{* * *}$ & $0.876^{* * *}$ & $0.825^{* * *}(0.000)$ & $0.858^{* * *}$ \\
\hline Log Population Exp & $0.281^{* *}$ & $0.252^{* * *}$ & $0.344^{* *}$ & $\left.0.125^{*}\right)$ & $0.357^{* * *}$ & $0.246^{* * *}(0.014)$ & 0.067 \\
\hline Log Population Imp & -0.004 & -0.026 & -0.001 & -0.027 & -0.024 & $0.001^{* * *}(0.988)$ & -0.022 \\
\hline Log LPI Exp & $0.251^{* * *}$ & & & & & & \\
\hline Log LPI Imp & $0.148^{* *}$ & & & & & & \\
\hline Log Customs Exp & & $0.229^{* * *}$ & & & & & \\
\hline Log Customs Imp & & $0.084^{*}$ & & & & & \\
\hline Log Infraestructure Exp & & & $0.282^{* * *}$ & & & & \\
\hline Log Infraestructure Imp & & & $0.141^{* *}$ & & & & \\
\hline Log Int Shipments Exp & & & & $0.135^{* * *}$ & & & \\
\hline Log Int Shipments Imp & & & & $0.131^{* * *}$ & & & \\
\hline Log Competence Exp & & & & & $0.298^{* * *}$ & & \\
\hline Log Competence Imp & & & & & $0.101^{*}$ & & \\
\hline Log Tracking Exp & & & & & & $0.213^{* * *}(0.000)$ & \\
\hline Log Tracking Imp & & & & & & $0.154^{* * *}(0.002)$ & \\
\hline Log Timeliness Exp & & & & & & & $0.091^{*}$ \\
\hline Log Timeliness Imp & & & & & & & $0.126^{* * *}$ \\
\hline Border & 0.037 & 0.035 & $0.036(0.343)$ & 0.037 & 0.035 & 0.036 & 0.037 \\
\hline Language & $0.026)$ & 0.030 & $0.035(0.441)$ & 0.031 & 0.034 & 0.026 & 0.030 \\
\hline Colony & 0.043 & 0.045 & $0.039(0.316)$ & $0.044^{*}$ & 0.043 & 0.042 & 0.047 \\
\hline Mills Lambda & -1.967 & -1.571 & $-1.933(0.534)$ & -1.277 & -1.684 & -1.956 & -1.462 \\
\hline
\end{tabular}

Note: ${ }^{*}$ p-value $<0.1,{ }^{* *} \mathrm{p}$-value $<0.05,{ }^{* * *} \mathrm{p}$-value $<0.01$ 
